\title{
Atmospheric N Deposition Increases Organic N Loss from Temperate Forests
}

\author{
E. N. J. Brookshire,$^{1 *}{ }^{\dagger}$ H. M. Valett, ${ }^{1}$ S. A. Thomas, ${ }^{2}$ and J. R. Webster ${ }^{1}$ \\ ${ }^{1}$ Department of Biological Sciences, Virginia Polytechnic Institute and State University, Blacksburg, Virginia 24061, USA \\ ${ }^{2}$ Department of Ecology and Evolutionary Biology, Cornell University, Ithaca, New York 14853, USA
}

\begin{abstract}
Atmospheric deposition of nitrogen $(\mathrm{N})$ resulting from fossil fuel combustion has increased $\mathrm{N}$ inputs to temperate forests worldwide with large consequences for forest productivity and water quality. Recent work has illustrated that dissolved organic $\mathrm{N}$ (DON) often dominates $\mathrm{N}$ loss from unpolluted forests and that the relative magnitude of dissolved inorganic $\mathrm{N}$ (DIN) loss increases with atmospheric loading. In contrast to DIN, DON loss is thought to be controlled by soil dynamics that operate independently of $\mathrm{N}$ supply and demand and thus should track dissolved organic carbon (DOC) following strict stoichiometric constraints. Conversely, DON loss may shift with $\mathrm{N}$ supply if soil (SOM) or dissolved organic matter (DOM) is stoichiometrically altered. Here, we assess these two explanations of DON loss, which we refer to as the Passive Carbon Vehicle and the Stoichiometric Enrichment hypotheses, by analyzing patterns in soil and stream $\mathrm{C}$ and $\mathrm{N}$ in forest watersheds spanning a broad gradient in atmospheric $\mathrm{N}$ loading (5-45 $\left.\mathrm{kg} \mathrm{N}^{-1} \mathrm{y}^{-1}\right)$. We
\end{abstract}

\section{INTRODUCTION}

Nitrogen-supply regulates biotic structure and function in many ecosystems (Vitousek and others 2002). For millennia, N limitation in most temperate forests has been maintained, in part, by low

Received 1 December 2005; accepted 23 August 2006 *Corresponding author; e-mail: ebrooksh@princeton.edu

${ }^{\dagger}$ Current address: Department of Ecology and Evolutionary Biology, Princeton University, Princeton, New Jersey 08544, USA show that soil $\mathrm{N}$ and DON losses are not static but rather increase asymptotically with $\mathrm{N}$ loading whereas soil C and DOC do not, resulting in enrichment of organic $\mathrm{N}$ expressed as decreased soil C:N and stream DOC:DON ratios. DON losses from unpolluted sites are consistent with conservative dissolution and transport of refractory SOM. As $\mathrm{N}$ supply increases, however, $\mathrm{N}$ enrichment of organic losses is greater than expected from simple dissolution of enriched soils, suggesting activation of novel pathways of DON production or direct $\mathrm{N}$ enrichment of DOM. We suggest that our two hypotheses represent domains of control over forest DON loss as $\mathrm{N}$ supply increases but also that stoichiometric enrichment of bulk soils alone cannot fully account for large DON losses in the most $\mathrm{N}$-polluted forests.

Key words: DON; temperate forests; atmospheric deposition; stoichiometry; watersheds; stream chemistry inputs from atmospheric deposition (that is, $<4$ $\mathrm{kg} \mathrm{ha}^{-1} \mathrm{y}^{-1}$; Holland and others 1999). In combination with low supply from biological fixation, high demand by plants and microbes and sequestration of $\mathrm{N}$ into soil organic pools can retard $\mathrm{N}$ losses from forest ecosystems over long timescales (Vitousek and others 2002). Under such conditions, dissolved organic N (DON) often dominates hydrologic N losses from soils and watersheds (Sollins and McCorision 1981; Perakis and Hedin 2002). Now, 
however, many temperate forests in the northern hemisphere receive $\mathrm{N}$ inputs from atmospheric deposition far above pre-industrial levels (Holland and others 1999). Although elevated N loading has caused shifts in forest $\mathrm{N}$ cycling globally (Aber and others 1998) and consequent increases in dissolved inorganic N (DIN) losses to stream waters (Perakis and Hedin 2002), most forest watersheds remain highly retentive of $\mathrm{N}$. Much of this additional $\mathrm{N}$ is suspected to be sequestered into soil organic matter (SOM; Van Breeman and others 2002), but we know little about the long-term consequences of $\mathrm{N}$ enrichment on $\mathrm{N}$ transfers between biota and SOM, and ultimately dissolved losses from watersheds.

The "N saturation" concept describes cases in which $\mathrm{N}$ supply exceeds biotic demand, resulting in the alleviation of $\mathrm{N}$ limitation and distinctly nonlinear increases in DIN fluxes from soils to stream waters (Ågren and Bosatta 1988; Aber and others 1989). In addition to decreases in biotic uptake, long-term $\mathrm{N}$ pollution can further exacerbate $\mathrm{N}$ losses by lowering the $\mathrm{C}: \mathrm{N}$ ratios of organic substrates that regulate rates of immobilization and mineralization, thus increasing nitrification rates and losses of nitrate- $\mathrm{N}\left(\mathrm{NO}_{3}-\mathrm{N}\right)$ from watersheds. Results from both theoretical and empirical studies have suggested that this occurs after thresholds of $\mathrm{N}$ loading and soil C:N ratios are breached (Aber and others 1998; Gundersen and others 1998). In contrast to DIN, the alteration of DON dynamics with $\mathrm{N}$ loading is a topic of considerable uncertainty. Some research has implied that DON losses from watersheds remain consistent across broad geographic areas that vary considerably in $\mathrm{N}$ loading rates (Perakis and Hedin 2002) whereas others have observed large and persistent increases in soil solution DON flux in long-term forest fertilization experiments (McDowell and others 2004; Pregitzer and others 2004). These contrasting observations lead us to propose two alternate hypotheses for explaining DON losses from temperate forests, the Passive Carbon Vehicle Hypothesis and the Stoichiometric Enrichment Hypothesis.

The passive carbon vehicle hypothesis argues that DON losses from watersheds are largely biounavailable compounds leaching from slow-turnover SOM in strict stoichiometric proportion with dissolved organic carbon (DOC; Hedin and others 1995; Rastetter and others 2005). Therefore, DON losses are under the control of SOM dissolution and transport rather than $\mathrm{N}$ demand and cycling. Under low $\mathrm{N}$ supply, dominance of hydrologic $\mathrm{N}$ losses by DON is also expected if $\mathrm{N}$ supply limits organic matter decomposition (Vitousek and others 2002; Aber and others 1998), resulting in C losses as DOC rather than $\mathrm{CO}_{2}$, with DON accompanying the DOC loss. Further, DON losses are maintained by the prevalence of DON in refractory humic substances (Thurman 1985; Qualls and Haines 1991) that render DON largely unavailable to higher plants and microorganisms (Qualls 2000). The power of this hypothesis is that it predicts both the higher than expected loss of DON under low $\mathrm{N}$ availability as well as lower than expected DON losses (as compared to DIN) in regions of high $\mathrm{N}$ deposition (Perakis and Hedin 2002). This hypothesis also relies on the notion that sorption does not prefer DOC or DON. Under high N loading rates, DON losses remain stable simply because dissolved organic matter (DOM) export is dominated by refractory compounds whose production is not directly tied to nitrogen cycling. Observed correlation between DOC and DON fluxes in soil and stream waters (Perakis and Hedin 2002; Michalzik and others 2001) support this hypothesis.

The passive carbon vehicle hypothesis is based on the prediction that DOM is stoichiometrically static. More recently, several researchers have documented increasing DON in soil solution when $\mathrm{N}$ loading has been experimentally increased (McDowell and others 2004; Pregitzer and others 2004). Further, these studies observed decreases in DOC:DON, suggesting that DOM leaching from soils may not be as stoichiometrically fixed as predicted by the passive carbon vehicle model. Stoichiometric enrichment of DOM could occur via two major pathways. First, stoichiometric alteration of the SOM pool, which has been observed with $\mathrm{N}$ loading (Aber and others 1989; Gundersen and others 1998), could be directly expressed in the DOM leaching from that pool, followed by 'passive' transport. In this case, DOM stoichiometry would simply mimic enriched source pools. Alternatively, stoichiometric enrichment could occur via direct $\mathrm{N}$ enrichment of DOM with or without prior enrichment of source pools. In this case, $\mathrm{C}: \mathrm{N}$ ratios of DOM would be lower than those of SOM. Regardless, the stoichiometric enrichment hypothesis predicts a disproportionate increase in DON export, relative to DOC, from watersheds exposed to chronic $\mathrm{N}$ deposition.

If increased DON production or loss with increasing $\mathrm{N}$ input is a general pattern, this would suggest that dominant processes controlling transfers of DIN to DON, and ultimately ecosystem $\mathrm{N}$ loss, may shift under conditions of chronically elevated $\mathrm{N}$ supply. This potential for increased DON production and loss with enhanced $\mathrm{N}$ loading has important implications for coupled $\mathrm{C}$ and $\mathrm{N}$ cycling 
Table 1. Characteristics of Study Watersheds

\begin{tabular}{|c|c|c|c|c|c|c|}
\hline Region & Watershed $^{1}$ & $\begin{array}{l}\mathrm{N} \text { input } \\
\left(\mathrm{kg} \mathrm{ha}^{-1} \mathrm{y}^{-1}\right)\end{array}$ & $\begin{array}{l}\text { Elevation } \\
\max (\mathrm{m})\end{array}$ & $\begin{array}{l}\text { Watershed } \\
\text { area (ha) }\end{array}$ & $\begin{array}{l}\text { Precipitation } \\
\left(\mathrm{mm}^{-1} \mathrm{y}\right)\end{array}$ & Vegetation \\
\hline \multirow[t]{5}{*}{ Coweeta } & Shope Branch (2) & 5.1 & 1,004 & 12 & 1,810 & $\mathrm{AD}$ \\
\hline & Hugh White Creek (14) & 5.6 & 992 & 61 & 1,870 & $\mathrm{AD}$ \\
\hline & Snake Den Branch (19) & 5.8 & 1,021 & 28 & 1,903 & $\mathrm{AD}$ \\
\hline & Pinnacle Branch (36) & 6.1 & 1,542 & 49 & 2,160 & $\mathrm{AD}$ \\
\hline & Upper Ball Creek (27) & 6.7 & 1,454 & 39 & 2,390 & $\mathrm{AD}$ \\
\hline \multirow[t]{4}{*}{ Joyce Kilmer } & Poplar Cove Branch & 7.7 & 1,098 & 17 & 1,951 & OD \\
\hline & No name & 7.7 & 915 & 24 & 1,837 & OD \\
\hline & Indian Spring Branch & 7.7 & 1,219 & 144 & 2,026 & OD \\
\hline & Adamcamp Branch & 7.7 & 1,463 & 161 & 2,178 & OD \\
\hline \multirow[t]{3}{*}{ GSMNP } & Noland Creek & 32.2 & 1,910 & 17 & 2,270 & OC \\
\hline & Clingmans Creek & 32.2 & 1,890 & 106 & 2,270 & $\mathrm{OC}$ \\
\hline & Beech Flats Prong & 32.2 & 1646 & 157 & 2,270 & OC \\
\hline \multirow[t]{4}{*}{ Fernow } & Spring run & 10.0 & 988 & 13 & 1,450 & $\mathrm{AD}$ \\
\hline & WS (4) & 10.0 & 870 & 39 & 1,458 & $\mathrm{AD}$ \\
\hline & WS (3) & 45.0 & 860 & 34 & 1,476 & $\mathrm{AD}$ \\
\hline & Wilson Hollow & 10.0 & 854 & 110 & 1,450 & $\mathrm{AD}$ \\
\hline
\end{tabular}

and long-term $\mathrm{N}$-limitation of production in both terrestrial and aquatic ecosystems. Given the nonlinear nature of ecosystem responses to N supply, it is possible that shifts in DON quantity or quality may only be evident over relatively long experimental timescales or across broad gradients of $\mathrm{N}$ loading. Alternatively, shifts in DON may simply be a transitory biogeochemical response to disturbance ( $\mathrm{N}$ loading) observed until systems reach a new steady state. Here we employ the 'small-watershed' approach (Bormann and Likens 1967) to analyze atmosphere-soil influences on DON losses from forests spanning a broad $\mathrm{N}$ loading gradient (5-45 $\mathrm{kg} \mathrm{N} \mathrm{ha}^{-1} \mathrm{y}^{-1}$ ) in the Appalachian Mts., USA. Our objective was to determine which of the models described above, the passive carbon vehicle model or the stoichiometric enrichment model, is most consistent with watershed scale patterns in DON loss in response to increasing $\mathrm{N}$ supply to forest ecosystems.

\section{Methods}

\section{Study Sites}

We restricted our sites to systems for which atmospheric deposition is known or has been modeled based on local data. Most sites are long-term research watersheds with extensive records of water and inorganic $\mathrm{N}$ fluxes and include well-documented cases of $\mathrm{N}$ saturation. All sites $(n=16)$ are unglaciated forested watersheds receiving 1,450$2,300 \mathrm{~mm} / \mathrm{y}^{-1}$ precipitation $(<10-14 \%$ as snow) but differ widely in forest composition and age (Table 1). Half of the sites were historically logged but were never under agriculture use and all have low abundances of the dominant $\mathrm{N}$ fixer Robinia. Soils at all sites are Inceptisols or Ultisols derived from sandstones.

The Coweeta Hydrologic Laboratory is a 2,185-ha area located in the Natahala Mountain Range of western North Carolina. Bedrock in the basin is composed of metasandstone, coarse-grained diorite gneiss, and interlayered muscovite. Soils consist of Dystrochrepts and Hapludults. Vegetation is dominated by aggrading ( $~ 80$ years old) mixed oak (Quercus), hickory (Carya), and tulip poplar (Liriodendron tulipifera) forest. Nitrogen deposition to Coweeta is low for the eastern USA and stream DIN concentrations are often near analytical detection limits, but $\mathrm{N}$ inputs generally increase with elevation (Swank and Vose 1997).

The Noland Divide study area is a 17-ha, highelevation (1,650-1,910 m) watershed within the Great Smoky Mountains National Park (GSMNP). Bedrock geology is dominated by feldspathic sandstone; soils consist of Dystrochrepts and Haplumbrepts. Vegetation is dominated by old-growth red spruce (Picea rubens) and understory Fraser fir (Abies fraseri) and birch (Betula). This site is believed to be $\mathrm{N}$-saturated, indicated by high $\mathrm{NO}_{3}-\mathrm{N}$ concentrations in stream water (Van Miegroet and 
others 2001). In 2002 and 2004, we sampled additional high elevation GSMNP streams located within $6 \mathrm{~km}$ of Noland Divide.

The Joyce Kilmer Memorial Forest is a 1,540-ha old-growth forest located in the Unicoi Mountains $\sim 60 \mathrm{~km}$ northwest of Coweeta and $\sim 20 \mathrm{~km}$ southwest of the GSMNP. This forest is similar in composition to Coweeta but has never been logged. Precipitation and temperature are also similar to Coweeta (K. Elliot USFS, personal communication). Geology consists of metasandstone and soils are classified as Dystrochrepts and Hapludults (Daniels and others 1987).

The Fernow Experimental Forest is a 1,902-ha area located in the Allegheny Mountains, in northern West Virginia. Bedrock consists of acidic sandstone and soils are classified as Dystrochrepts (Adams and others 1997). Overstory vegetation is dominated by aggrading sugar maple (Acer sachrum), cherry (Prunus), beech (Fagus grandifolia), and oak. Symptoms of $\mathrm{N}$ saturation in this forest include high and non-seasonal stream $\mathrm{NO}_{3}-\mathrm{N}$ concentrations (Peterjohn and others 1996). We focused sampling in WS 4 and WS 3 which are the subjects of a long-term paired-watershed (WS 4 is the control) experiment; WS 3 has been helicopterfertilized with ammonium sulfate since 1989 (Gilliam and others 1996). Briefly, WS 3 was treated in the spring, summer, and fall of each year to more closely mimic the timing of atmospheric inputs to these forests. The spring and fall applications were $7.1 \mathrm{~kg} \mathrm{~N} / \mathrm{ha}^{-1}$ and the summer application was 21.3 $\mathrm{kg} \mathrm{N} / \mathrm{ha}^{-1}$. The effects of sulfur fertilization were not addressed in this study. In July 2004 and April 2005, we sampled additional streams in the Fernow area.

\section{Atmospheric N Deposition and Water Fluxes}

We used data on total (wet + dry) inorganic $\mathrm{N}$ $\left(\mathrm{NO}_{3}-\mathrm{N}+\right.$ ammonium- $\left.\mathrm{N}\left[\mathrm{NH}_{4}-\mathrm{N}\right]\right)$ deposition in all analyses. Data on organic $\mathrm{N}$ deposition were not available for most sites. Long-term water and $\mathrm{N}$ fluxes for Coweeta watersheds are from Swank and Vose (1997) and considered representative of recent deposition (J. Vose, USFS Coweeta Hydrologic Laboratory, personal communication). Total $\mathrm{N}$ deposition to the Joyce Kilmer forest was estimated using a simple model based on long-term data from Coweeta and Smokies deposition, local precipitation, and contribution from cloud deposition ( $\mathrm{K}$. Elliot, USFS Coweeta Hydrologic Laboratory, personal communication). This estimate was applied to all Joyce Kilmer watersheds. Long-term water and $\mathrm{N}$ deposition fluxes to the Noland Divide watershed are from Van Miegroet and others (2001) and applied to the other high-elevation GSMNP watersheds. Long-term mean deposition to Fernow WS 3 and WS 4 was provided by M.B. Adams (USFS Northeastern Forest Experiment Station, personal communication), and water fluxes are from Adams and others (1993). Watershed 3 represented our highest $\mathrm{N}$ loading watershed $(45 \mathrm{~kg} \mathrm{~N}$ $\mathrm{ha}^{-1} \mathrm{y}^{-1}$; supplied in part by experimental additions). The deposition rate in WS 4 was applied to other watersheds sampled in the Fernow area.

\section{Soil Sampling and Analysis}

Soils were collected in July over 2002-2004 in Coweeta watersheds and Fernow WS 4. Duplicate cores $(5 \mathrm{~cm}$ diameter) consisting of forest floor (Oe + Oa) and mineral soils $(0-10 \mathrm{~cm})$ were collected from 14 approximately $1-\mathrm{m}^{2}$ areas distributed in a random manner in near-stream $(0.5-2 \mathrm{~m}$ from the stream edge) and hillslope ( 20-40 m upslope from stream edge) watershed positions. Soils from these two positions were combined in all statistical analyses after initial analysis revealed no significant differences in $\mathrm{C}$ and $\mathrm{N}$ concentrations or pools. In the laboratory soils were dried to a constant weight at $60^{\circ} \mathrm{C}$ for determination of bulk density. Combined duplicate cores were separated into forest floor and mineral horizons, sieved $(2 \mathrm{~mm})$, and fine roots $(<2 \mathrm{~mm})$ were carefully removed and discarded. Sub-samples of root- and rock-free soil were ground using a mortar and pestle and analyzed for $\mathrm{C}$ and $\mathrm{N}$ content using a Variomax CNS analyzer (Elementar, Germany). Carbon and $\mathrm{N}$ pools were calculated by multiplying element concentrations by bulk density.

We supplemented our soil analyses with comparable soil core $(0-10 \mathrm{~cm})$ data for the Noland Divide watershed collected by $\mathrm{H}$. Van Miegroet ( $n=50$, unpublished data), WS 3 in Fernow with data from M. B. Adams ( $n=35$, unpublished data), and Joyce Kilmer using information from Daniels and others (1987). Soil data for the Joyce Kilmer forest were not available for individual watersheds in which stream water was collected. Instead, we used mean soil characteristics calculated from eight large sites distributed throughout the forest. We used mineral soil data in analyses of watershed $\mathrm{N}$ losses because we lacked data for organic soils for some sites and because differences in horizon classification and sampling across studies confounded calculation of organic pools. Further, we assumed that although organic layers may dominate $\mathrm{N}$ transformation and DOM production, 
mineral soils effectively integrate long-term retention and hydrologic transport relevant to DON fluxes occurring along subsurface flowpaths to streams (Qualls 2000; Aitkenhead-Peterson and others 2003).

\section{Stream Water Chemistry}

Replicate stream water samples $(n=4-10 /$ date $)$ were collected from the base of study watersheds from 2002 to 2005. Streams were sampled at least twice, with most sampled in July of 2002 and 2004. This period spanned relatively low (2002) and high (2003) precipitation years for the southern and central Appalachian region. Over this same period, Coweeta streams were intensively sampled $(n=170)$ to assess seasonal variation in DON. All samples were filtered (Whatman ${ }^{\circledR} \mathrm{GF} / \mathrm{F}$, pore size $=0.7 \mu \mathrm{m})$ in the field into acid-washed polyethylene bottles and frozen until chemical analysis. Nitrate- $\mathrm{N}$ was determined colorometrically following the acidic diazo method after cadmium reduction (Wood and others 1967) on a Technicon Auto Analyzer II (Technicon, Emeryville, California, USA). Ammonium-N was analyzed colorometrically following an automated phenate method (Soloranzo 1969). Total dissolved N (TDN) was determined by high temperature potassium persulfate oxidation followed by analysis of nitrate. DON was calculated by difference as TDN $-\left(\mathrm{NO}_{3}-\mathrm{N}\right.$ $\left.+\mathrm{NH}_{4}-\mathrm{N}\right)$ using l-glutamic acid as a reference standard (APHA and others 1998). Beginning in 2003, all water samples were analyzed for DOC by sodium persulfate oxidation using an Oceanographic International (OI) Model 700 Total Organic Carbon Analyzer (Menzel and Vaccaro 1964; Oceanographic International, College Station, USA). We used an OI Model 1010 for 2004 samples. Analyses of external standards run on both instruments yielded equivalent results. Method detection limits were $\mathrm{NO}_{3}-\mathrm{N} 3 \mu \mathrm{g} / \mathrm{L}, \mathrm{NH}_{4}-\mathrm{N} 3 \mu \mathrm{g} / \mathrm{L}$, DON $15 \mu \mathrm{g} / \mathrm{L}$, and DOC $0.1 \mathrm{mg} / \mathrm{L}$. We assigned a value half the detection limit for samples below these detection limits.

\section{Data Analysis}

We used regression analysis to examine relationships between $\mathrm{N}$ loading, soil C:N, soil pools, and stream chemistry and to assess relationships among DOC, DIN, and DON. Although our data were confined to four geographic regions, we justified use of non-linear regression based on a sample size of nine independent measures of $\mathrm{N}$ deposition. We addressed the influence of $\mathrm{N}$ deposition on DON after accounting for the concomitant influences of forest type and age, elevation, and precipitation using stepwise multiple regression analysis. For analyses of watershed exports, we only used sites $(n=6)$ for which there were long-term water and $\mathrm{N}$ flux data. We calculated hydrologic export by multiplying the long-term mean annual discharge by average $\mathrm{N}$ concentrations. We were confident in this approach as a rough estimate of yield because there was little intra-site difference in stream chemistry between hydrologically contrasting years of sampling and because systematic variation in chemistry across the $\mathrm{N}$ loading gradient was much greater than variation in stream discharge across watersheds. Further, we found no systematic changes in DON concentrations by season in Coweeta streams. We tested for differences in water chemistry between Fernow fertilized and control watersheds using two-way (treatment, season) analysis of variance of stream nutrient concentrations.

\section{RESUltS}

\section{Soil C:N Ratios and Pools}

Organic and shallow mineral soil C:N ratios were highly similar and declined ( 30-17) with $\mathrm{N}$ loading from 5.1-10 kg N ha-1 $\mathrm{y}^{-1}$, followed by little change up to $45 \mathrm{~kg} \mathrm{~N} \mathrm{ha}^{-1} \mathrm{y}^{-1}$ (Figure 1A). This initial decline in $\mathrm{C}: \mathrm{N}$ corresponded to linear increases in total (organic + mineral horizon) soil $\mathrm{N}$ pools $\left(r^{2}=0.98, \quad P=0.0015\right)$ with $\mathrm{N}$ loading. Across all sites, mineral soil $\mathrm{C}: \mathrm{N}$ ratios were inversely related to $\mathrm{N}$ pool size $\left(r^{2}=0.57 ; P=0.019\right)$ resulting from logarithmic increases in mineral soil $\mathrm{N}$ (Figure 1B). In contrast, mineral soil $\mathrm{C}$ varied from $24-36 \mathrm{Mg} / \mathrm{ha}^{-1}$ but did not change $(P>0.2)$ with $\mathrm{N}$ supply.

\section{Stream Chemistry and Watershed Export}

Concentrations of DON in stream water increased significantly and asymptotically over the N-loading gradient (Figure 2A). This increase was also significant $\left(r^{2}=0.33, P=0.0079\right)$ but linear across the smaller and more geographically constrained 5.1$7.7 \mathrm{~kg} \mathrm{~N} \mathrm{ha}^{-1} \mathrm{y}^{-1}$ gradient. Although observed increases in DON were driven largely by differences between Coweeta and our two high $\mathrm{N}$ regions, deposition was the only significant variable explaining stream DON across all sites in a stepwise multiple regression model $\left(F_{1,14}=38.63, R^{2}=0.75\right.$, $P<0.0001)$. In contrast, $\mathrm{N}$ deposition $(P<0.0001)$, elevation $(P=0.0254)$, precipitation $(P=0.0006)$, and forest type $(P=0.0001)$ were strong predictors of stream water $\mathrm{NO}_{3}-\mathrm{N}\left(F_{4,14}=112.27, R^{2}=0.98\right.$, 

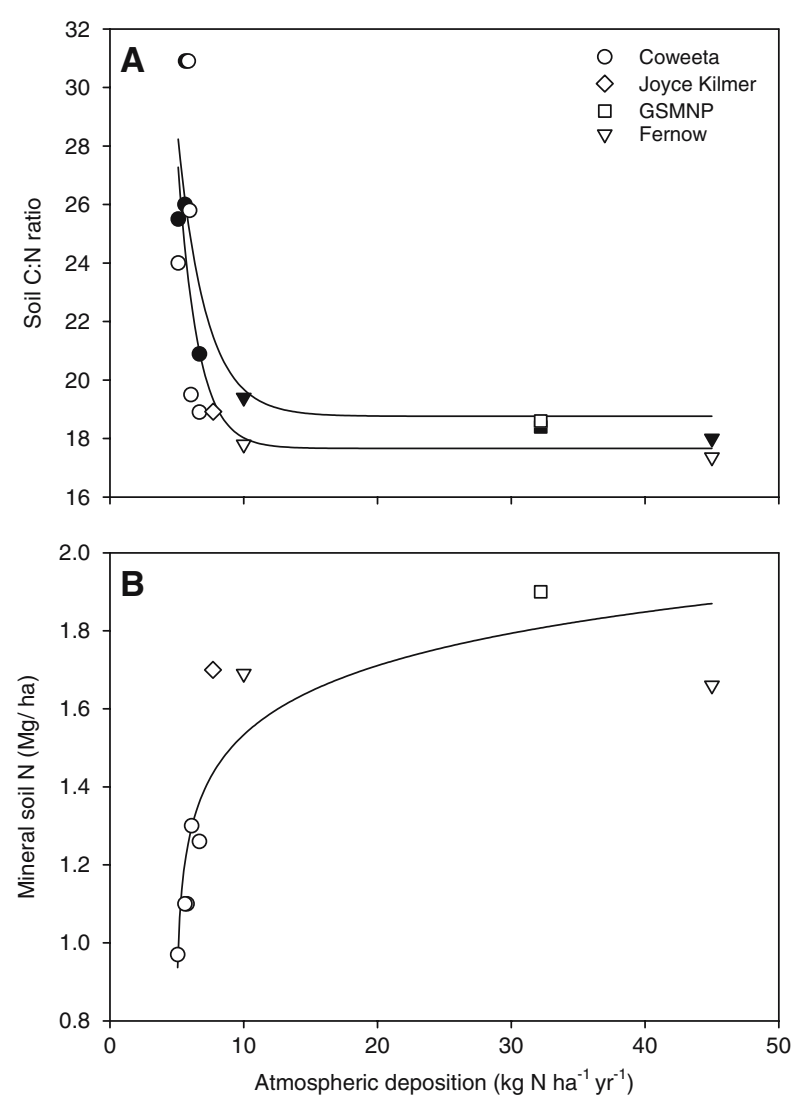

Figure 1. Mean organic (filled symbols) and mineral (open symbols) soil C:N ratios (by mass) (A) and mineral soil $\mathrm{N}$ pools (B) as function of atmospheric $\mathrm{N}$ loading. Site symbols apply to all figures. The relationship between organic soil $\mathrm{C}: \mathrm{N}$ ratios versus $\mathrm{N}$ input was explained by the equation $y=18.76+107.11 e^{-0.47 x} ; \quad r^{2}=0.72$, $P=0.079$. The relationship between mineral soil $\mathrm{C}: \mathrm{N}$ ratios versus $\mathrm{N}$ input was explained by the equation $y=17.66+290 e^{-0.67 x} ; r^{2}=0.58, P=0.076$. The relationship between soil $\mathrm{N}$ versus loading was explained by the equation $y=1.27+0.16 \times \ln (x-4.93) ; r^{2}=0.79$, $P=0.0097$.

$P<0.0001)$. Concentrations of $\mathrm{NO}_{3}-\mathrm{N}$ increased more with $\mathrm{N}$ loading than DON (Figure 2A), resulting in a shift in DIN:DON ratios from $<1$ to $>1$ in watersheds receiving more than $7 \mathrm{~kg} \mathrm{~N} \mathrm{ha}^{-1} \mathrm{y}^{-1}$. Ammonium- $\mathrm{N}$ was universally low $(<4 \mu \mathrm{g} / \mathrm{l})$, driving a greater than 500 -fold increase in $\mathrm{NO}_{3}-\mathrm{N} \mathrm{NH}_{4}-$ $\mathrm{N}$ ratios $(2-1,074)$ over the $\mathrm{N}$-loading gradient. Concentrations of DOC were consistently low $(<3$ $\mathrm{mg} / \mathrm{l})$ and decreased slightly with $\mathrm{N}$ loading $\left(F_{1,13}=5.01, R^{2}=0.29, P=0.045\right)$, although this pattern was driven largely by differences in sampling intensity (high $\mathrm{N}$ sites were not sampled in the fall when DOC is higher). Stream DOC:DON ratios also declined significantly and non-linearly with $\mathrm{N}$ loading $\left(r^{2}=0.57, P<0.001\right)$. Across the entire $\mathrm{N}$
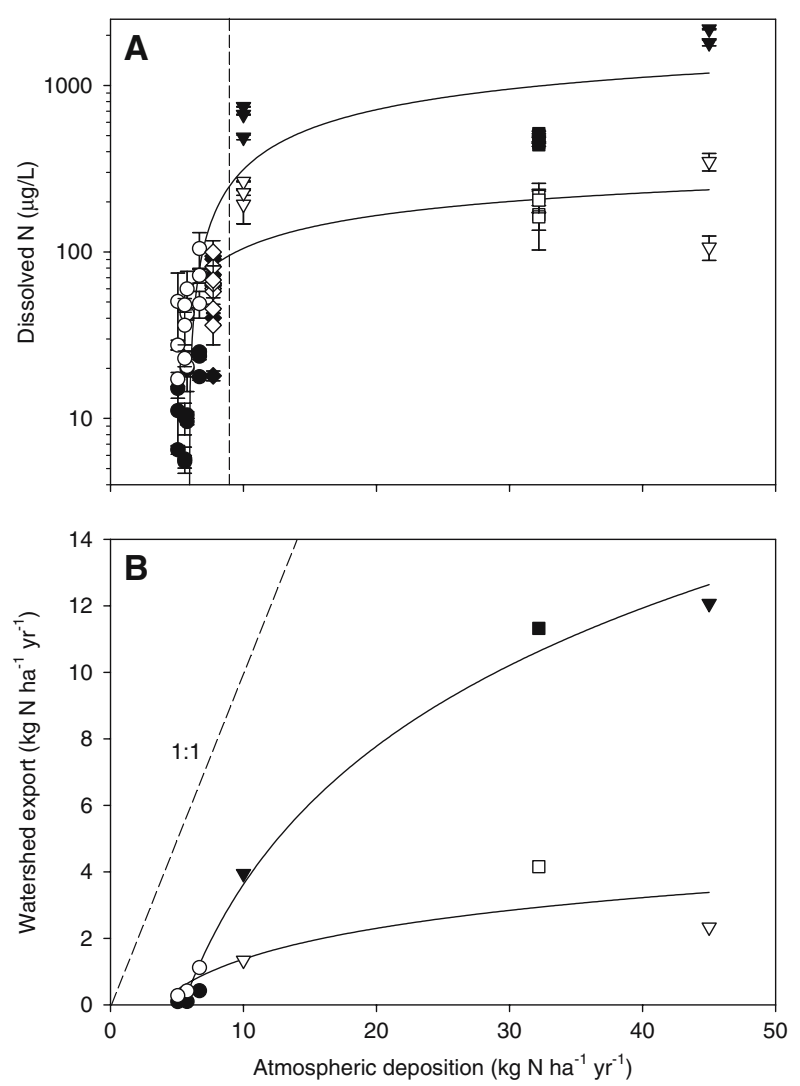

Figure 2. Mean ( $\pm \mathrm{SE})$ DON (open symbols) and $\mathrm{NO}_{3}-\mathrm{N}$ (closed symbols) concentrations collected in study streams over 2002-2005 (A) and watershed N exports (B) as a function of atmospheric $\mathrm{N}$ loading. In panel $\mathbf{A}$, each point represents the mean of all samples collected within a stream and year. Export was calculated only for sites with long-term discharge data. Relationships between DON and $\mathrm{NO}_{3}-\mathrm{N}$ concentration and load versus $\mathrm{N}$ input were explained by the following equations: DON concentration $=-95.97+87.27 \times \ln (x), r^{2}=0.54,<0.0001$; $\mathrm{NO}_{3}-\mathrm{N}$ concentration $=-1024.56+580.64 \times \ln (x)$, $r^{2}=0.63, P<0.0001 ;$ DON load $=-1.69+1.33 \times \ln (x)$; $r^{2}=0.74, P<0.0001 ; \mathrm{NO}_{3}-\mathrm{N}$ load $=-10.18+5.99 \times \mathrm{ln}$ $\left.(x) ; r^{2}=0.99, P<0.0001\right)$. Note $\log$ scale on $y$-axis in panel A. Vertical dashed line in panel $\mathbf{A}$ indicates approximate $\mathrm{N}$ input value where DON concentration increases but losses switch from DON > DIN to DIN > DON. Symbols as in Figure 1.

loading gradient, DON was strongly associated with $\mathrm{NO}_{3}-\mathrm{N}\left(r^{2}=0.77, \quad P<0.0001\right)$ but not DOC $\left(r^{2}=0.04, P=0.13\right)$. This pattern also held for the low-N Coweeta watersheds where DON was aseasonal (unpublished manuscript) and more closely associated with $\mathrm{NO}_{3}-\mathrm{N}\left(r^{2}=0.30, P<0.0001\right)$ than DOC $\left(r^{2}=0.11, P<0.0001\right)$.

These patterns of $\mathrm{N}$ loss were further supported by significantly higher DON $\left(F_{5,34}=28.03\right.$, $R^{2}=0.83, P<0.0001$; treatment $\left.P=0.0059\right)$ and 
$\mathrm{NO}_{3}-\mathrm{N} \quad\left(F_{5,34}=411.37, \quad R^{2}=0.99, \quad P<0.0001 ;\right.$ treatment $P<0.0001)$ in fertilized versus control watersheds in Fernow. In these watersheds DON was lower and $\mathrm{NO}_{3}-\mathrm{N}$ was higher $(P<0.001)$ in winter vs. summer samples. There was also a greater response in $\mathrm{NO}_{3}-\mathrm{N}$ (that is, $0.23 \mathrm{~kg} \mathrm{~N}^{-1}$ $\mathrm{y}^{-1}$ increase in loss per $\mathrm{kg} \mathrm{ha}^{-1} \mathrm{y}^{-1} \mathrm{~N}$ added) than DON (0.021 kg N ha ${ }^{-1} \mathrm{y}^{-1}$ increase in loss) to longterm $\mathrm{N}$ fertilization.

Exports of DON and $\mathrm{NO}_{3}-\mathrm{N}$ increased logarithmically with atmospheric $\mathrm{N}$ loading (Figure 2B) and more for $\mathrm{NO}_{3}-\mathrm{N}\left(0.09-12.1 \mathrm{~kg} \mathrm{~N} \mathrm{ha}^{-1} \mathrm{y}^{-1}\right)$ than DON (0.3-4.2 $\left.\mathrm{kg} \mathrm{N} \mathrm{ha}^{-1} \mathrm{y}^{-1}\right)$. Our DON export estimate for Noland Divide $\left(4.2 \mathrm{~kg} \mathrm{~N} \mathrm{ha}^{-1} \mathrm{y}^{-1}\right)$ was lower than that based on volume-weighted means (5.5 $\mathrm{kg} \mathrm{N} \mathrm{ha}^{-1} \mathrm{y}^{-1}, \mathrm{H}$. Van Miegroet, unpublished data) but this difference did not affect overall patterns relating DON export and $\mathrm{N}$ loading. Losses of $\mathrm{NH}_{4}$ - $\mathrm{N}$ were low $\left(0.02-0.07 \mathrm{~kg} \mathrm{~N} \mathrm{ha}^{-1} \mathrm{y}^{-1}\right)$ and did not vary with $\mathrm{N}$ loading. Despite increasing losses, annual hydrologic losses of $\mathrm{N}$ were only $8-50 \%$ of atmospheric input rates across all watersheds.

\section{Atmosphere-Soil-Stream Linkages and Organic Matter Stoichiometry}

Stream DON (Figure 3A) and $\mathrm{NO}_{3}-\mathrm{N}$ concentrations increased asymptotically with decreasing C:N ratios in both mineral $(P<0.001)$ and organic $(P<0.001)$ soils across the $\mathrm{N}$ loading gradient. This pattern was not attributable to changes in soil $\mathrm{C}$, but rather strong increases in DON $\left(r^{2}=0.69\right.$, $P=0.0002)$ and $\mathrm{NO}_{3}-\mathrm{N}\left(r^{2}=0.45, P=0.009\right)$ with increasing soil $\mathrm{N}$ pool size. Concentrations of DOC did not vary with soil $\mathrm{C}: \mathrm{N}$ ratios or $\mathrm{C}$ pools $(P>0.2)$. Comparison of DOC:DON ratios in stream water and mineral soil C:N revealed a steep decline in stream water DOC:DON as soil C:N decreases (Figure 3B). Stream water DOC:DON drops substantially below the 1:1 line relating bulk soils (assumed source) and stream solution as soil C:N declines, suggesting a proportionally greater $\mathrm{N}$ enrichment in dissolved compared to solid organic pools.

\section{Discussion}

\section{Chronic N Loading and Patterns of DON Formation and Loss}

Our study revealed distinct increases in DON loss with increasing $\mathrm{N}$ supply. This pattern was characterized by steep initial increases followed by little change with additional $\mathrm{N}$ loading. Patterns in stream water $\mathrm{N}$ in our study paralleled those from
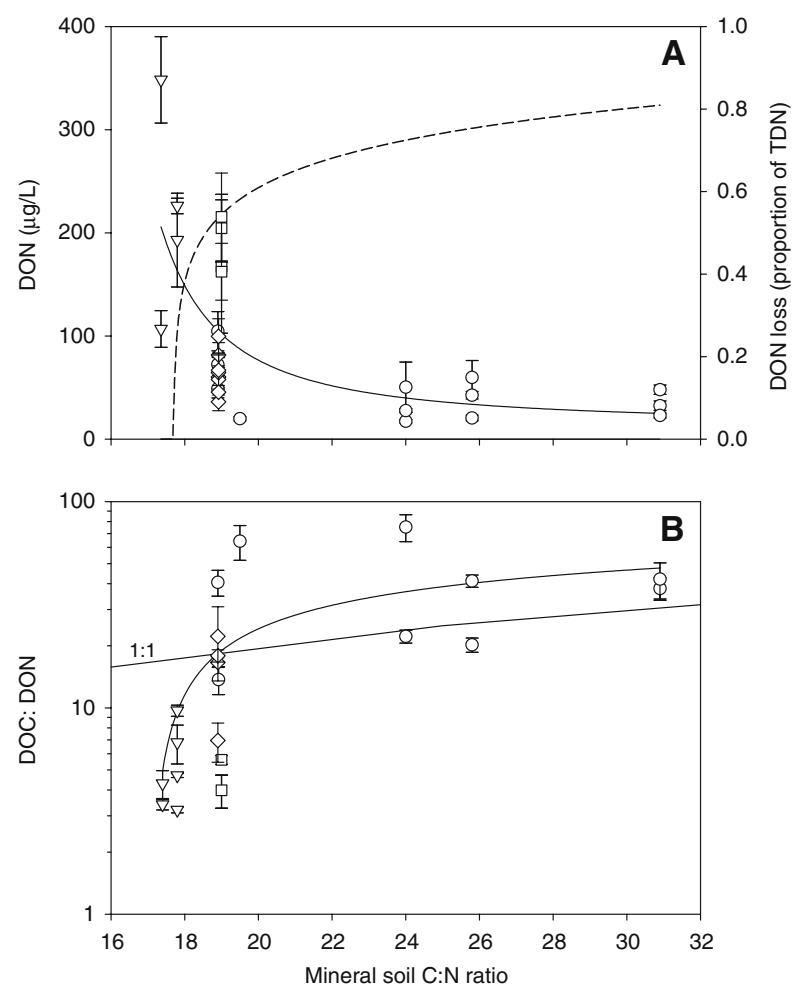

Figure 3. Mean annual DON concentrations and the proportion of TDN as DON (dashed line) in stream water (A) and mean DOC:DON ratios in stream water $(\mathbf{B})$ as a function of mean catchment mineral soil C:N ratios (note $\log$ scale on $y$-axis). The relationship between DON and mineral soil $\mathrm{C}: \mathrm{N}$ ratio was explained by the equation: $y=11.27 \times \mathrm{e}^{(14.87 /[x-12.24])} ; r^{2}=0.43, P=0.0063$. The relationship between the stream water DOC:DON ratio and mineral soil $\mathrm{C}: \mathrm{N}$ ratio was explained by the equation $y=11.06+13.54 \times \ln (x-16.93) ; r^{2}=0.52, P=0.0184$. Sample size differs between panels because DOC was not measured in 2002. Symbols as in Figure 1.

other studies showing dominance of DON over $\mathrm{NO}_{3}-\mathrm{N}$ and $\mathrm{NH}_{4}-\mathrm{N}$ in unpolluted temperate forest watersheds (Sollins and McCorison 1981; Hedin and others 1995) and reversal of this pattern as a consequence of chronic $\mathrm{N}$ pollution (Perakis and Hedin 2002). Patterns of nutrient loss from our relatively unpolluted sites were generally consistent with the passive carbon vehicle model of DON loss. In contrast, we suggest that stoichiometric enrichment of DOM resulting from increased $\mathrm{N}$ supply explains the observed increase in DON losses from polluted forests. Further, simple dissolution and transport of $\mathrm{N}$-enriched SOM at the most polluted sites cannot fully account for observed DON losses, suggesting activation of unknown $\mathrm{N}$ pools or direct $\mathrm{N}$ enrichment of DOM along catchment flowpaths. 
Although processes underlying the shift toward DIN losses with increasing $\mathrm{N}$ inputs are becoming better understood (Perakis and others 2005), changes in the relative losses of DOC and DON in the face of increasing $\mathrm{N}$ deposition depend on longterm feedbacks among elevated $\mathrm{N}$, immobilization, and sequestration into soils that remain largely unknown. Further, transport of DOM through soils is strongly influenced by hydrology and mineral sorption (Neff and others 2000; Aitkenhead-Peterson and others 2003). However, there is little evidence for preferential hydrologic or sorption affinity for DOC versus DON as DOM percolates through forest soils (Qualls 2000). Thus, although there are numerous factors (for example, climate, biome, soil mineralogy, ecosystem type) that potentially influence soluble soil $\mathrm{N}$ pools and DON fluxes (Qualls 2000; Michalzik and others 2001) not addressed in this study, we contend that observed increases in DON losses were driven by $\mathrm{N}$ supply. If mechanisms controlling the solubility of DOM remain constant (that is, constant leak rates from slow-turnover SOM despite changing deposition), and flow paths mix in a simple conservative manner, the low DOC:DON ratios observed in high $\mathrm{N}$ deposition watersheds in this and other studies require a substantial shift in SOM stoichiometry or contributions of N-rich DOM from unknown sources. This prediction is borne out by comparison of DON versus DOC relationships from our study and other temperate forest streams spanning a wide range of $\mathrm{N}$ loading (Figure 4), illustrating that the slope of the DON versus DOC line describing stream losses becomes progressively steeper with increased $\mathrm{N}$ supply. Indeed, across the $\mathrm{N}$ loading gradient, patterns of DON loss were not related to DOC, but rather, DIN.

By definition, organic $\mathrm{N}$ is inextricably linked to the 'carbon vehicles' in which it is transported and thus our two hypotheses represent domains in a gradient of control by static versus dynamic DOM stoichiometry as $\mathrm{N}$ supply increases. That is, although fixed stoichiometric coupling of DON and DOC may provide an adequate model for understanding DON loss from low-N ecosystems, our results indicate that an alternative model is required to capture the dynamics of DON flux as $\mathrm{N}$ availability increases. If DON simply tracks DOC following strict stoichiometric constraints, DON loss should increase proportionally with soil C pool size and, assuming static soil stoichiometry, C:N ratios (Rastetter and others 2005). Strong positive correlation between river DOC fluxes, soil C pools, and $\mathrm{C}: \mathrm{N}$ ratios across biomes have been observed (Aitkenhead and McDowell 2000). In addition, tight

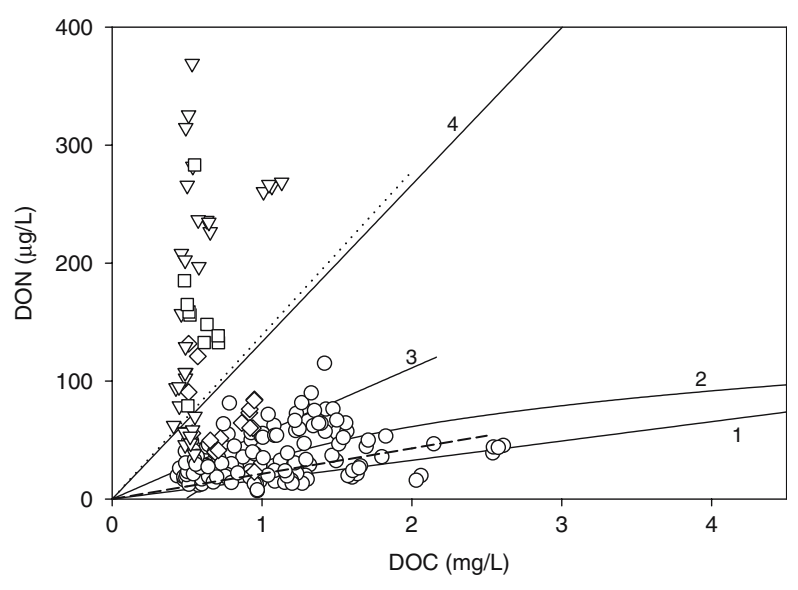

Figure 4. DON and DOC in stream water across varying levels of atmospheric $\mathrm{N}$ deposition. Symbols represent stream samples from this study, and dotted and dashed lines represent mean DOC:DON ratios from sites receiving greater than or less than $7 \mathrm{~kg} \mathrm{~N} \mathrm{ha}^{-1} \mathrm{y}^{-1}$, respectively. Numbered lines are DON versus DOC regression lines from (1) temperate South America, $<3 \mathrm{~kg} \mathrm{~N}^{-1} \mathrm{y}^{-1}$ (Perakis and Hedin 2002), (2) White Mountains USA, 9 -11 kg $\mathrm{N} \mathrm{ha}{ }^{-1} \mathrm{y}^{-1}$ (Goodale and others 2000), (3) Catskill Mountains USA, $\sim 12 \mathrm{~kg} \mathrm{~N} \mathrm{ha}^{-1} \mathrm{y}^{-1}$ (Lovett and others 2000), and (4) Noland Divide USA, $32.2 \mathrm{~kg} \mathrm{~N} \mathrm{ha}^{-1} \mathrm{y}^{-1}$ (H. Van Miegroet, unpublished data). Symbols as in Figure 1.

correlations between DOC and DON in temperate soil (Michalzik and others 2001) and stream waters (Goodale and others 2000; Perakis and Hedin 2002) have also been reported. Together, these studies support the passive carbon vehicle model of DON losses. In contrast, increasing fluxes of DON have been observed when soil $\mathrm{N}$ pools increase due to soil age (Neff and others 2000) and abundance of $\mathrm{N}$-fixing trees (Compton and others 2003). Soil N accumulation may also help explain generally higher DON losses from tropical versus temperate forests (Lewis and others 1999). As soil N pools grow, SOM C:N should decrease and there should be a concomitant increase in DON losses per unit loss of carbon, assuming that SOM represents the dominant sink for $\mathrm{N}$ and that chronic levels of $\mathrm{N}$ input do not contribute substantially to ecosystem C sequestration (Nadelhoffer and others 2004). We did not observe consistent shifts in C pools with $\mathrm{N}$ loading but did observe changes in DON flux that were tightly associated with soil N pools, DIN losses, and soil C:N.

Our results are consistent with widely reported lower soil $\mathrm{C}: \mathrm{N}$ ratios and associated higher nitrification rates in watersheds receiving high $\mathrm{N}$ deposition (Aber and others 1998; Gundersen and others 1998). Strong negative association between 
$\mathrm{NO}_{3}-\mathrm{N}$ and DOC:DON in stream waters (Goodale and others 2000; Campbell and others 2000; Lovett and others 2000) has also been interpreted as an integrator of watershed soil C: $\mathrm{N}$ ratios and $\mathrm{N}$ status. Our results complement these findings and are consistent with studies indicating that $\mathrm{C}: \mathrm{N}$ ratios of DOM are generally similar to or higher than those of bulk SOM (Goodale and others 2000). In contrast, DOC:DON ratios fall below SOM values at our chronically N-polluted sites, implying that sources of additional DON are not fully captured by bulk soil characteristics. This suggests the possibility that $\mathrm{N}$ enrichment of DOM occurs locally via reaction with DIN in solution but is not expressed in solid pools or, alternatively, occurs farther down soil-tostream flowpaths.

Most $\mathrm{N}$ in forest soils is thought to be bound in highly stable humic materials derived from condensation reactions with polyphenols and quinones (Stevenson 1994; Qualls 2000). If steady state $\mathrm{N}$ dynamics respond to inputs as a function of pool residence time, increased deposition should not increase DON losses if $\mathrm{N}$ pools are large (relative to inputs) and turn over slowly. Observed increases in DON losses thus would suggest activation of novel pathways of organic $\mathrm{N}$ production as ecosystems approach critical states of $\mathrm{N}$ supply. Also, higher DON losses at polluted sites could occur if a large portion of the $\mathrm{N}$ pool derived from long-term anthropogenic $\mathrm{N}$ loading turns over relatively rapidly (that is, decades). Regardless, declines in the DOC:DON ratio with $\mathrm{N}$ loading observed in our study and plot-scale fertilization experiments (McDowell and others 2004; Pregitzer and others 2004) are consistent with stoichiometric enrichment of DOM. Plot-scale $\mathrm{N}$ fertilization experiments have produced mixed results with regard to DOC production, with some reporting increases in DOC (Pregitzer and others 2004) and others showing no change in DOC fluxes with $\mathrm{N}$ enrichment (McDowell and others 2004). High levels of hydrophilic compounds, including aminerich DOM exuded by mycorrhizae (AitkenheadPeterson and others 2003), may contribute directly to DON fluxes (and reduced DOC:DON) under N addition (McDowell and others 2004). Given the large capacity for mineral soil to retain DOM (Qualls 2000), increased losses to stream water are surprising and thus imply saturation of sorption sites or shifts in the composition of DOM toward smaller, more neutral molecules (for example, hydrophilic compounds) that sorb poorly to mineral soils (Kaiser and Zech 2000). Further, because plant demand for amino acid $\mathrm{N}$ should decrease in high N systems (Neff and others 2003;
Schimel and Bennett 2004), increases in DON may reflect greater export of bioavailable forms as $\mathrm{N}$ demand saturates. Alternatively, increased DON could result from decreased mineralization via depressed microbial activity (Pregitzer and others 2004), acid release of low C:N humic compounds (Stevenson 1994), or abiotic N sorption to humic DOM (Aber and others 1998; Kaizer and Zech 2000).

\section{DON, N Saturation, and Implications for Watershed Ecosystems}

Our results suggest that increases in DON losses are asymptotic and that once a threshold $\mathrm{N}$ input level has been exceeded little change in DON losses are observed. This relationship may be indicative of fundamental limitations on soil $\mathrm{N}$ accumulation or DON production and transport. This implies that soil N capital, and thus DON loss, plateaus as gaseous and DIN loss vectors increase. This is best illustrated by the Fernow and GSMNP watersheds; all have similar mineral soil $\mathrm{N}$ pools and DON losses despite a three- to five-fold difference in $\mathrm{N}$ loading. In contrast, losses as highly mobile $\mathrm{NO}_{3}-\mathrm{N}$ would ultimately be expected to approach unity with inputs as abiotic and biotic compartments saturate as a result of chronic $\mathrm{N}$ exposure (Gundersen and others 1998). The potential implications of increased DON losses for ecosystem $\mathrm{N}$ limitation depend to a large degree on whether increases are compensatory (that is, constancy in TDN loss rates but shifts in forms) versus additive (constancy in DIN loss rates and increases in TDN losses). Transformation of $\mathrm{NO}_{3}-\mathrm{N}$ to DON may enhance watershed $\mathrm{N}$ retention even under chronically polluted conditions because of the much greater affinity of soil sorption sites for DOM versus $\mathrm{NO}_{3}-\mathrm{N}$. Conversely, additive formation and loss of DON may dampen $\mathrm{N}$ saturation and further prolong $\mathrm{N}$ limitation (Hedin and others 1995) even as $\mathrm{N}$ supply grows. As reported for other systems (Goodale and others 2000), watersheds in our study remained highly retentive of $\mathrm{N}$ after inclusion of DON losses even in systems receiving more than 15 times pre-industrial deposition rates and under oldgrowth conditions, consistent with sequestration into soils (Nadelhoffer and others 2004). Assuming that gaseous $\mathrm{N}$ losses represent a small contribution to apparent retention relative to hydrologic losses (Van Breeman and others 2002), inclusion of DON losses in our study failed to balance $\mathrm{N}$ inputs (DIN input $>$ TDN output), resulting in net ecosystem retention of $\sim 4-30 \mathrm{~kg} \mathrm{~N} \mathrm{ha}^{-1} \mathrm{y}^{-1}$ or $50-92 \%$ of inputs. 
In this investigation we have used patterns in stream water chemistry to understand watershed scale responses to chronic $\mathrm{N}$ loading. This approach integrates production, uptake, and retention processes occurring in all terrestrial and aquatic watershed subsystems. Although much of our analysis points to atmosphere-soil control over DOM losses, we recognize that DIN, DOC, and DON can undergo substantial uptake and transformation in surface and subsurface components of streams (Brookshire and others 2005). Therefore, patterns presented in this study represent net watershed processing. Indeed, there is potential for $\mathrm{N}$-induced shifts in DOM to affect aquatic metabolism and $\mathrm{N}$ cycling. Given the low bioavailability of DOM (Qualls and Haines 1991) at low N sites, however, we suspect that stream transformation of DOM is dominated by internal cycling of labile forms (Brookshire and others 2005). Although C and N contained in amino acids can be tightly cycled in terrestrial and aquatic ecosystems (Neff and others 2003), free amino acids typically make up less than $1 \%$ of the DOM pool (Thurman 1985). Decreased DOC:DON ratios at $\mathrm{N}$ polluted sites may suggest increases in DOM lability, and thus potentially increases in aquatic $\mathrm{C}$ demand. However, because analogous patterns of saturation of $\mathrm{N}$ uptake occur in streams (Payn and others 2005), we expect that higher loads of DON in N saturated watersheds may be exported farther downstream, with subsequent potential for mineralization and eutrophication of previously enriched rivers and estuaries (Seitzinger and Sanders 1997). Although many questions remain regarding the production and fate of DON in temperate forest watersheds, our results suggest that current theory regarding ecosystem $\mathrm{N}$ retention and loss needs to encompass an understanding of the role of DON under conditions of high levels of long-term $\mathrm{N}$ deposition.

\section{ACKNOWLEDGEMENTS}

We are very grateful to Mary Beth Adams and Helga Van Miegroet for sharing unpublished data for the Fernow Experimental Forest and the Noland Divide watershed, respectively. Johanna Barron assisted with field work. Reviews by Joe Yavitt, Nancy Grimm, and two anonymous reviewers significantly improved this manuscript. This research was supported by NSF grant DEB 04-05373.

\section{REFERENCES}

Aber JD, Nadelhoffer KJ, Steudler P, Melillo JM. 1989. Nitrogen saturation in northern forest ecosytems. BioScience 39:37886.
Aber J, McDowell W, Nadelhoffer K, Magill A, Bernston G, Kamakea M, McNulty S, Currie W, Rustad L, Fernandez I. 1998. Nitrogen saturation in temperate forest ecosystems. BioScience 48:921-34.

Adams MB, Kochenderfer JN, Wood F, Angradi TR, Edwards P. 1993. Forty years of hydrometerological data from the Fernow Experimental Forest, West Virginia. USDA Forest Service General Technical Report, NE-184.

Adams MB, Angradi TR, Kochenderfer JN. 1997. Stream water and soil solution responses to 5 years of nitrogen and sulfur additions at the Fernow Experimental Forest, West Virginia. Forest Ecol Manag 95:79-91.

Ågren GL, Bosatta E. 1988. Nitrogen saturation of terrestrial ecosystems. Environ Pollut 54:185-97.

Aitkenhead JA, McDowell WH. 2000. Soil C:N ratio as a predictor of annual riverine DOC flux at local and global scales. Global Biogeochem Cycle 14:127-38.

Aitkenhead-Peterson JA, McDowell WH, Neff JC. 2003. Sources, production, and regulation of allochthonous dissolved organic matter inputs to surface waters. In: Findlay SEG, Sinsabaugh RL Eds. Aquatic ecosystems- Interactivity of dissolved organic matter. San Diego, CA: Academic Press. p 25-70.

American Public Health Association(APHA), American Water Works Association, Water Environment Federation 1998. Standard Methods for Examination of Water and Wastewater. 20th edn. Washington, DC: American Public Health Association.

Bormann FH, Likens GE. 1967. Nutrient cycling. Science 155: 424-9.

Brookshire ENJ, Valett HM, Thomas SA, Webster JR. 2005. Coupled cycling of dissolved organic nitrogen and carbon in a forest stream. Ecology 86:2487-96.

Campbell JL, Hornbeck JR, McDowell WH, Busoi DC, Shanley JB, Likens GE. 2000. Dissolved organic nitrogen budgets for upland forested ecosystems in New England. Biogeochemistry 49:123-42.

Compton JE, Church MR, Larned ST, Hogsett WE. 2003. Nitrogen export from forested watersheds in the Oregon Coast Range: The role of $\mathrm{N}_{2}$-fixing red alder. Ecosystems 6:773-85.

Daniels WL, Zelazny LW, Everett CJ. 1987. Virgin hardwood forest soils of the Southern Appalachian Mountains: II. Weathering, mineralogy, and chemical properties. Soil Sci Soc Am J 51:722-9.

Gilliam FS, Adams MB, Yurish BM. 1996. Ecosystem nutrient responses to chronic nitrogen inputs at Fernow Experimental Forest, West Virginia. Can J Forest Res 26:196-205.

Goodale CL, Aber JD, McDowell WH. 2000. The long-term effects of disturbance on organic nitrogen export in the White Mountains, New Hampshire. Ecosystems 3:433-50.

Gundersen P, Emmet BA, Kjonaas OJ, Koopmans CJ, Tietema A. 1998. Impact of nitrogen deposition on nitrogen cycling in forests: a synthesis of NITREX data. Forest Ecol Manag 101:37-55.

Hedin LO, Armesto JJ, Johnson AH. 1995. Patterns of nutrient loss from unpolluted, old-growth temperate forests: evaluation of biogeochemical theory. Ecology 76:493-509.

Holland EA, Dentener FJ, Braswell BH, Sulzman JM. 1999. Contemporary and pre-industrial global reactive nitrogen budgets. Biogeochemistry 46:7-43.

Kaiser K, Zech W. 2000. Sorption of dissolved organic nitrogen by acid subsoil horizons and individual mineral phases. Eur $\mathrm{J}$ Soil Sci 51:403-11. 
Lewis WM, Melack JM, McDowell WH, McClain M, Richey JE. 1999. Nitrogen yields from undisturbed watersheds in the Americas. Biogeochemistry 46:149-162.

Lovett GM, Weathers KC, Sobczak WV. 2000. Nitrogen saturation and retention in forested watersheds of the Catskill Mountains, New York. Ecol Appl 10:73-84.

McDowell WH, Magill AH, Aitkenhead-Peterson JA, Aber JD, Merriam JL, Kaushal SJ. 2004. Effects of chronic nitrogen amendment on dissolved organic matter and inorganic nitrogen in soil solution. Forest Ecol Manag 196:29-41.

Menzel DW, Vaccaro RF. 1964. The measurement of dissolved organic and particulate carbon in seawater. Limnol Oceanogr 9:138-42.

Michalzik B, Kalibitz J, Park H, Solinger S, Matzner E. 2001. Fluxes and concentrations of dissolved organic carbon and nitrogen-a synthesis for temperate forests. Biogeochemistry 52:173-205.

Nadelhoffer KJ, Coleman BJ, Currie WJ, Magill A, Aber JD. 2004. Decadal-scale fates of ${ }^{15} \mathrm{~N}$ tracers added to oak and pine stands under ambient and elevated $\mathrm{N}$ inputs at the Harvard Forest (USA). Forest Ecol Manage 196:89-107.

Neff JC, Hobbie SE, Vitousek PM. 2000. Nutrient and mineralogical control on dissolved organic $\mathrm{C}, \mathrm{N}$, and $\mathrm{P}$ fluxes and stoichiometry in Hawaiian soils. Biogeochemistry 51:283-302.

Neff JC, Chapin FS, Vitousek PM. 2003. Breaks in the cycle: dissolved organic nitrogen in terrestrial ecosystems. Front Ecol Environ 1:205-11.

Payn RA, Webster JR, Mulholland PJ, Valett HM, Dodds WK. 2005. Estimation of stream nutrient uptake from nutrient addition experiments. Limnol Oceanogr Methods 3:174-82.

Perakis SS, Hedin LO. 2002. Nitrogen loss from unpolluted South American forests mainly via dissolved organic compounds. Nature 415:416-9.

Perakis SS, Compton JE, Hedin LO. 2005. Nitrogen retention across a gradient of ${ }^{15} \mathrm{~N}$ additions to an unpolluted temperate forest soil in Chile. Ecology 86:96-105.

Peterjohn WT, Adams MB, Gilliam FS. 1996. Symptoms of nitrogen saturation in two central Appalachian hardwood forest ecosystems. Biogeochemistry 35:507-22.

Pregitzer KS, Zak DR, Burton AJ, Ashby JA, Macdonald NW. 2004. Chronic nitrate additions dramatically increase the export of carbon and nitrogen from northern hardwood ecosystems. Biogeochemistry 68:179-197.
Qualls RG. 2000. Comparison of the behavior of soluble organic and inorganic nutrients in forest soils. Forest Ecol Manage 138:29-50.

Qualls RG, Haines BL. 1991. Biodegradability of dissolved organic matter in forest throughfall, soil solution, and stream water. Soil Sci Soc Am J 56:578-86.

Rastetter EB, Perakis SS, Shaver GR, Ågren GI. 2005. Terrestrial $\mathrm{C}$ sequestration at elevated $\mathrm{CO}_{2}$ and temperature: the role of dissolved organic nitrogen loss. Ecol Appl 15:71-86.

Schimel JP, Bennett J. 2004. Nitrogen mineralization: challenges of a changing paradigm. Ecology 85:591-602.

Seitzinger SP, Sanders RW. 1997. Contribution of dissolved organic nitrogen from rivers to estuarine eutrophication. Mar Ecol Prog Ser 159:1-12.

Sollins P, McCorison FM. 1981. Nitrogen and carbon solution chemistry of an old growth coniferous forest watershed before and after cutting. Water Resour Res 17:1409-18.

Soloranzo L. 1969. Determination of ammonia in natural waters by the phenolhypochlorite method. Limnol Oceanogr 14:799801 .

Stevenson FJ. 1994. Humus chemistry. New York: Wiley.

Swank WT, Vose JM. 1997. Long-term nitrogen dynamics of Coweeta forested watersheds in the southeastern United States of America. Global Biogeochem Cycle 11:657-71.

Thurman EM. 1985. Organic geochemistry of natural waters. Dodreck: Nihoff/Junk.

Van Breemen N, Boyer EW, Goodale CL, Jaworski NA, Paustin K, Seitzinger SP, Lajtha K, Mayer B, Van Dam D, Howarth RW, Nadelhoffer KJ, Eve M, Billen G. 2002. Where did all the nitrogen go? Fate of nitrogen inputs to large watersheds in the northeastern U.S.A. Biogeochemistry 57/58:267-93.

Van Miegroet H, Creed IF, Nicholas NS, Tarboton DG, Webster KL, Shubzda J, Robinson B, Smoot J, Johnson DW, Lindberg SE, Lovett G, Nodvin S, Moore S. 2001. Is there synchronicity in nitrogen input and output fluxes at the Noland Divide Watershed, a small N-saturated forested catchment in the Great Smoky Mountains National Park? Sci World $1: 480-92$.

Vitousek PM, Hättenschwiler S, Olander L, Allison S. 2002. Nitrogen and nature. Ambio 31:97-101.

Wood ED, Armstrong FAJ, Richards FA. 1967. Determination of nitrate in seawater by cadmium-copper reduction to nitrite. $\mathrm{J}$ Mar Biol Assoc UK 47:23-31. 